日本農薬学会誌 18，S61-S68（1993）

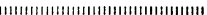

解

説

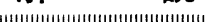

\section{Agrochemistry and Biology Series}

\section{食飼料素材中の有害物質}

\author{
葛 西隆 則 \\ 北海道大学農学部生物機能化学科
}

(平成 5 年 2 月 20 日受理)

\title{
Detrimental Substances in Materials for Food- and Feedstuff
}

\author{
Takanori KASAI \\ Department of Bioscience and Chemistry, Faculty of Agriculture, \\ Hokkaido University, Kita-ku, Sapporo 060, Japan
}

\section{は じめに}

自然食品は健康食品，すなわち自然二健康，という等 式が喧层され浸透し，ほとんど常識のようになってい る.スーパーマーケットには, 無農薬無化学合成肥料栽 培をうたう“自然食”が一画を占め，専門店も増えてい る. 化学合成品を諸悪の源とし，そのようなものを使用 していない産物，食品を推奖する説を載せた雑誌，書物 は文字どおりあふれており，多数の著作をもつある食品 評論家はその著書の中で「それくらい自然というもの は，人類の生存のためにうむくできているのである」と 断言しているほどである.もっとも，その文の前段で， 「ビタミンを除く栄養素は自然の食品におのずから含ま れているものであり…」いいう箇所があるように基本的 な誤りの多い著書ではあるが，先の著者は消費者運動に は強い影響力るもっているという。しかし，本小論は自 然食品を礼賛する著作群の基本的な間違いを指摘するも のではなく, 自然二健康，という等式への素朴な疑問を 呈するものである.

食う，というときその対象は，いうまでるなく自分と 異なる他の生物である。しかし，食われるために存在し ている生物など存在するはずもなく，食う，食われると いう関係は，自分は他の生物に食われまいとタテ(盾) を強化しながら，同様に食われないために強化している 他の生物の防御を破るためのホコ (矛) を磿き続けてい る，ということであり，盾か矛の一方の強化を止めた種 は衰退していくことになろう．特に，自ら動くことのな い植物は，自己の体内に捕食者に害作用を与える物質を
蓄積している場合が多い，そのように他の生物に食われ ないために自己を物理的化学的手段で守っている自然の 生物を, ヒトのために存在しているヒトのための健康食 品, とする考光がどうしてか常識のように広く受け入れ られている.

生物は自分とその種が生きていくために，自分と構造 も機能も異なる。したがって物質組成の異なる，そして しばしば他者に食われないための防御物質を含んでいる 他の生物を，試行錯誤を繰り返して食えるもの食えない ものを学習し選別しながら食い続けていかねばならな い、ヒトはさらにその過程で有害作用を及ぼす対象を避 けるだけではなく，その対象から有害成分を除き，可食 部分の利用性と嘴好性を高める処理方法を開発してき た. そのような方法の開発向上こそ, 食品学, 食品加工 学，等の分野の目的なのだが，ここでも食品素材はでき るだけ収穫された状態に手を加えずに摂取することが望 ましい，という考光方が，自然は七トの食品に適するよ うにデザインされているわけではないにもかかわらず広 く受け入れられており, 食品素材の加工は, その生産者 々消費者の居住地域が離れているため, その輸送, 貯蔵 時の品質低下を防ぐためのやむをえ始段，必要悪と考 えられがちである。

毎年毒茸等による中毒事故が発生しても, 食べてはい けないものを食べたのだから中毒するのは当然, とあっ さりわりきり, 自然物, 天然物礼賛は摇るがない。しか し，食べてはいけないもの，ではなく食べようとして食 べている，あるいは飼料として食べさせている食飼料素 材中にもヒトあるいは家畜に対して有害作用を及ぼす物 
表 1 食飼料中の有害物質

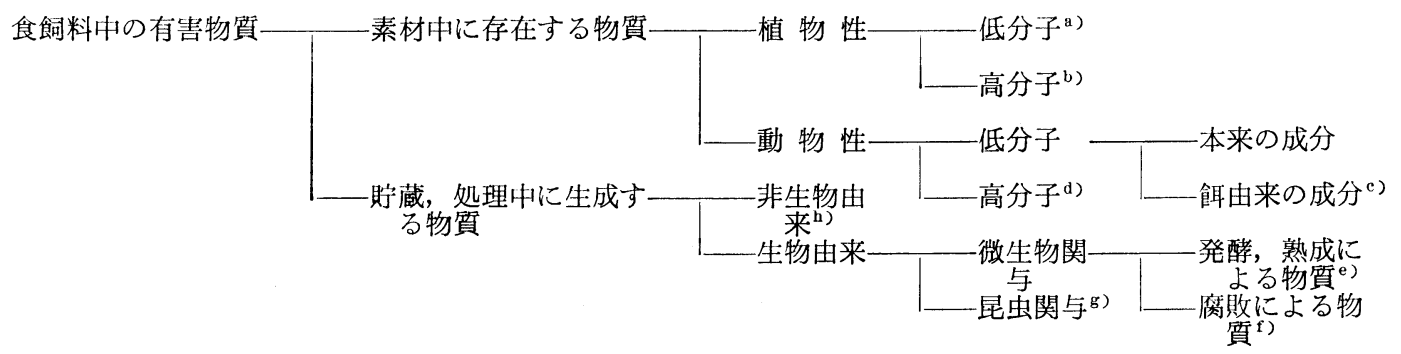

a)この小論では紙数の制限もあり，以下の本文では主にここに属する反栄養素の代表的なものを記し，その他 の項目に属する反栄養素群については, 以下゙注にととめる.

b) 高分子性の酵素反応阻害物質 (protease inhibitor 等), 生体に必要な物質を分解する酵素 (thiaminase 等), 生体に有害な物質を生成する酵素 (lipoxygenase 等)，レクチン，アレルゲン.

c) 魚介類の有毒物質の多くはここに属する。貝毒のうち, 麻痶性の saxitoxin, 下集性の dinophysistoxin, 神 経毒性の neosurugatoxin 等. ふぐ毒の tetrodotoxin も䬣由来と考えられている.

d) 鯉等淡水魚の thiaminase, うなぎ等の血清タンパク質, 卵白の avidin.

e) 発酵, 腐敗, 共に微生物の繁殖によるものであり, そのうち目的物質を生産する場合が発酵なのだから, 発 酵産物に有害物質がある, といらのは矛盾であるが, 通常の状態では有効, あるいは問題にならない物質 が，特殊な状況下で有害作用を現わす場合がある，チーズ，ワイン等の熟成中に生ずる多数のアミン，たと えば tyramine 法正常状態では monoamine oxidase により分解されるが，この酵素作用が阻害される状態 (抗うつ剂のような薬物掑取時) では血圧上昇を引き起こす。抗うつ刻治療を受けながら，気分高揚のため にチーズを食べてワインを飲む，という行為は危険な場合がある.

f) これも低分子性のものと高分子性のものに分けられる. 低分子性のものとしては aflatoxin, ochratoxin, patulin, 等の発癌物質, 高分子性ではボッリスス毒素, ぶどう状球菌の産生する毒性タンパク質等.

g) コクゾウムシの生成するキノン類等.

h) 加熱, 燻煙, 酸・アルカリ処理, 照射, 溶媒抽出, 等により生ずる有害物質 (褐変, 酸化, 重合, 等の反応 による.たとえば, 3,4-benzpyrene, アミンのニトロソ化により生ずる nitrosoamine 等の発癌物質). 酸に より亜鉛容器から溶出する塩化亜鉛, 硫酸亜鉛. トウモロコシの三塩化チッ素処理により生ずる methioninesulfoximine は, glutamine, methionine の代謝拮抗䯇として作用するが， その後民間薬として使用 されるコウトウマメモドキ科汇属するある種の植物の成分であることが判明した. 最初非天然物として見出 され，後に天然物としても存在することが証明された珍しい例である。

質, 反栄養素が含まれていることをこの小論で紹介した い、したがって，毒茸その他の有毒植物，一ビ，サソ リ，八チ，その他の有毒動物等一般的な食飼料素材では ないものの有害成分については触れない。

食飼料中の有害物質は, 表 1 の上うに大まかに分類す ることができる。

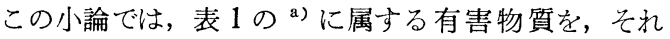
を含む植物が摄取される地域, 普遍的に症状発現がみら れるかぞうか, 等に基づいて分類し, 代表的な有害物質 を简単に紹介する。

\section{広く栽培されている食飼料植物に存在する有害物殡}

\section{1. 摄取による症状発現が普遍的で, 人種差, 地域差 が低いもの}

1) カラシ油配糖体 (Glucosinolate)

図 1 に示す構造をもつカラシ油配糖体はアブラナ科植 物 (アブラナ, ワサビ，キャベッ，カブ，ダイコン，等)
に多く含まれ，特有の風味に寄与していると同時に申状 腺肥大の原因物質である. カラシ油配糖体とその加水分 解酵素である thioglucosidase は共存しているが，正 常状態では両者は細胞内で隔離されて存在しているため 䤃素反応は起こらない，植物体が物理的に壊されると醉 素作用とそれに続く分解, 西るいは分子内転移反応を受 けて, イソチオシアネート (R-NCS), ニトリル (R$\mathrm{CN})$ ，チオシアネート (R-SCN) 等を生ずる. 代表的 なカラシ油配糖体である progoitrin(1) では, イソチ オシアネートはさらに環化して goitrin(2) となり,こ の goitrin が甲状腺ホルモンである thyroxine の合成 を阻害して甲状腺肥大を引き起こす，むた，別の代表的 カラシ油配糖体である $\operatorname{sinalbin(3)}$ から生ずるイソチ オシアネートはさらに 4-hydroxybenzyl alcohol と thiocyanate ion $\left(\mathrm{SCN}^{-}\right)$に分解されるが，この thiocyanate ion も甲状腺のヨウ素取り込久を阻害し， 甲状腺肥大の原因となる。 thiocyanate ion の影響はヨ 
ウ素供給を増せば防ぎうるが，goitrinによる甲状腺肥 大効果はヨウ素により除去できない。すり下ろしたワサ ビ，ダィコンの辛みも上記の酵素反応により生ずるイソ チオシアネート (ワサビの辛味前駆物質は $\operatorname{sinigrin}(4)$, ダイコンは $(\mathbf{5}))$ によるもので, 夫婦煊啭の後のダイコ ンおろしは辛い，といわれるのは，喧嘩で腹をたてた奥 様が怒りを込めてダイコンをすり下ろすので基質と酵素 が十分混ざり合い，イソチオシアネートが多量生ずるた め，とされるが，たと它喧嘩の後でも奥様が食事の用意 をしたという，遠い過去の話であろう. カラシ油配糖体 の分解生成物の一つであるニトリルのあるものも肝臟,

腎藏, 膵藏に毒性であることが知られており, カラシ油 配糖体は甲状腺肥大の原因物質としてのほか, 体器官に 対する影響も注目されている.カラシ油配糖体を除去 したナタネ種子分離タンパク質のタンパク質効率は caseinよりも優れている. なお，ナタネの英名は rape だが，最近はこの語感が嫌われ canola と呼ばれるよう になってきている(図 1).

2) 青酸配糖体 (Cyanogenic glycoside)

一般には毒というとすぐ連想される青酸だが，自然界 には青酸の発生につながる前駆物質である青酸配糖体の 分布は非常に広く, 2000 種以上の植物に存在している. その多くはバラ科, 、メ科, イネ科, トゥダイグサ科に 集中しており, そのうち植物可食部に存在し, 毒性が問 題となるのは amygdalin(6) (バラ科の多くの核果), $\operatorname{dhurrin}(7)$ (イネ科), linamarin $(8)$ (phaseolunatin, 発展途上国で非常に多く消費されるキャッサバ, リマ豆 中に多量, その他アマ種子), methyl linamarin(9) (lotaustralin，分布は linamarin と同じ) である. 青
酸配糖体とその分解酵素 $\beta$-glucosidase は上記のカラ シ油配糖体と thioglucosidase の場合と同様正常状態 では分かれて存在しているが，細胞が物理的に破壊され ると両者が接触して酵素反応が起き, 青酸が放出され る. キャッサバはレトにとっても動物にとっても非常に 重要なエネルギー源であるが，不十分な処理による中毒 が何世紀にもわたって知られている. 青酸の cytochrome $c$ oxidase に対する強い親和性による細胞呼吸 停止という急性中毒のほか，少量摄取が続いた場合には 慢性毒性が生じてくる. キャッサバ消費地域での失調性 神経障害は青酸の慢性中毒によると考えられている. 青 酸は rhodanase により thiocyanate ion として解毒さ れるが，これは前述のように甲状腺肥大物質であるほ か，ニトロソ化の強力な触媒であることから，たとえば 低塩酸症等で硝酸還元菌の成育が盛んな場合, 唾液中の isothiocyanate ion 含量が高いと nitrosoamine を生 ずる危険性がある.「ウメの核果の中身も食べてほしい。 含まれている amygdalin という物質は米国では制癌剤 として使われているほど良いもの」という宣伝もあった が，1960７0 年代に Laetrile という名で制癌剤とし て販売された amygdalin については，その後「Laetrile は毒物であり, 癌治療効果はない」との公式表明が 出されている(図 2).

3) Gossypol

ワタの種子 (綿実) は綿緎維生産時の副産物である が，油，タンパク質を豊富に含み綿実油源となるほか, 脱脂種子もタンパク質源として重要であり, 全脱脂綿奏 の約 1/4 で世界のタンパク質不足を補うことができる といわれている.しかし，綿奏にはセスキテルペン二量
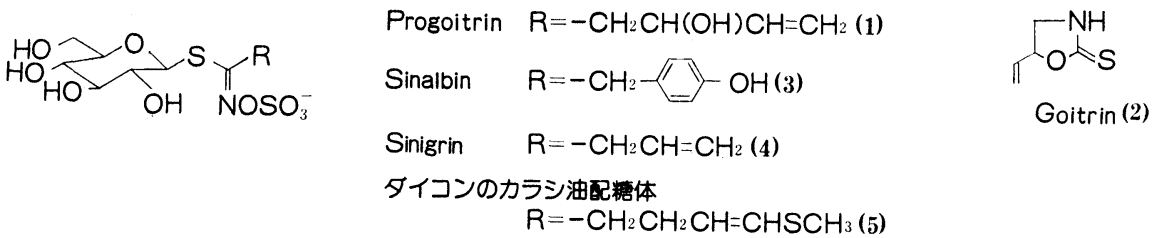

図1 カラシ油配糖体の構造式

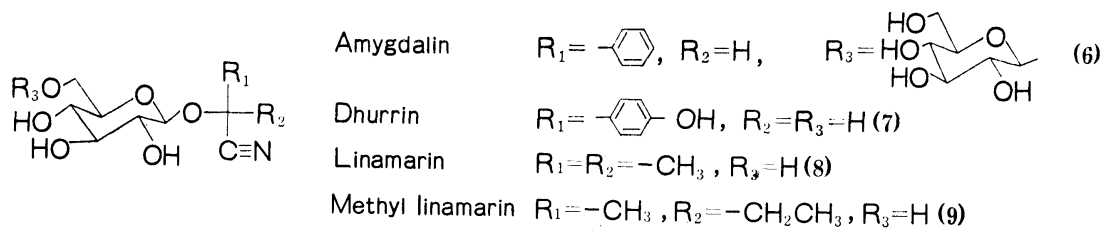

図 2 青酸配糖体の構造式 


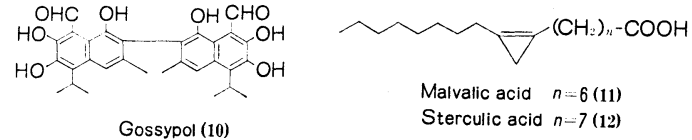

図 3 Gossyfol 色素およびシクロプロペン酸の構 造式

体の gossypol 色素が少なくとも15 種含まれており， その毒性が問題になる．量的に最も多く重要なのは非常 に反応性に富む黄色色素の gossypol(10) で，その反応 性の高さが特異性の低い酵素阻害作用やタンパク質の有 効性 lysine の低下に関与していると考えられる. 致死 量は低いが長期投与ではかなり強い毒性を発揮し最大の 死因は心不全で，肺浮腫もみられるが，毒性の大部分は 赤血球の酸素運搬能を低下させるため，とされている. また，gossypol は雄生殖能力低下を引き起こすが，飼 料としたときの最も鋭敏な反応は鷄卵黄身の変色(緑化) である，一方，綿実による鶏卵卵白の赤化は，シクロプ ロペン環をもつ malvalic acid(11) と sterculic acid (12)によるもので，これらは gossyfol と対照的に雌 の生殖能を低下させる. 脱脂綿実を与えた豚脂は融点が 高いが，これは残留油に含まれるシクロプロペン酸が stearic acid $\rightarrow$ oleic acid の変換を阻害するため，とさ れている(図 3).

4) サポニン (Saponin)

サポニンはステロイド $\left(\mathrm{C}_{27}\right)$ あるいはトリテルペノ イド $\left(\mathrm{C}_{30}\right)$ をアグリコンとする配糖体で，広範囲の植物 に存在している、トリテルペノイドサポニンは分布が広 く，100以上の科で見出されているが，それに比ベステ ロイドサポニンの分布は狭く，特に食飼料植物では少な い. 食飼料の面から重要なのはアルファルファとダイズ のサポニンでありそのアグリコンは共に soyasafogenol A， B C C D , E 犬゙が，ダイズサポニンのみが溶血性 を示す。サポゲニンと糖の比がアルファルファで $1: 5$, ダイズで 1:1 であり，溶血性は分子全体の柾水性に相 関するとされている.サポニンのもつ小腸粘膜障害，溶 血性，さらに殺虫性，抗菌性，はそのアグリコン部分が 脂質二重層膜に入り込み膜構造が変化するためと考えら れている.サポニンの消化管からの吸収は非常にわずか だが，上記のような小腸粘膜の障害が進行した状態では 消化管から吸収され，全身性の障害を引き起こす可能性 がある.サポゲニンにはそのようなサポニンの性質はみ られない。この小論では触れないが，特にジャガイモで 問題となるグリコアルカロイドでもアグリコンには配糖 体のような強い毒性はみられず，糖が外れて毒性を発現

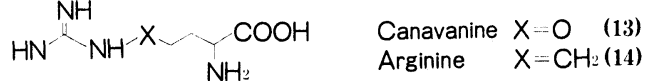

図 4 Canavanine および Arginine の構造式

する上記のカラシ油配糖体，青酸配糖体等とは対照的で ある。一般に甲状腺ホルモンは大部分が glucuronic acid 抱合体として胆汁を介して消化管内に排泄され， 腸内細菌によりその結合が切られホルモンは再び腸から 吸収されるが，サポニンはその再吸収を妨げるため糞便 中に失われるホルモン量が増し，上記のカラシ油配糖体 の場合と同様甲状腺肥大の原因となる。

5) Canavanine

Canavanine (13) は多数のマメ科植物種子中に存在し ており,タンパクアミノ酸である arginine $(14)$ と構造 が非常に近いことから， arginineのタンパク質への取 り込久，代謝と拮抗することによる害作用が知られてい る. 種子中に蓄積されている canavanine は発牙中急 激に減少，消失するとされているが，アルファルファで は発来中 canavanine が减少せず，食用に供されるア ルファルファもやし中にも canavanine が含まれてい るという報告もある(図 4).

\section{2. 症状発現に人種差, 地域差がみられるもの}

1) ファビズム (Favism)

ソラマメ摂取による溶血性貧血をファビズムといい, 地域差, 人種差が大きく, 地中海沿岸, 中近東で頻度が 高い。ソラマメは栽培地域が広くその歴史も非常に長い のにファビズムに地域差が認められるのは不思議である が，ファビズム症状を発現するヒトの赤血球の還元型 glutathione 含量は通常のヒトより低く, さらにファ ビズム症状発現中に急減する。 また, glucose-6-phosphate dehydrogenase(G6PD) の著しい不足が伴っ ている. G6PD 久損はヒトの遺伝的酵素久損症として は最も一般的なものであるが人種間差がある。ただし， G6PD 欠損者が常にファビズムを発現するわけではな い.たとえば米国黒人男性の G6PD 欠損者ではその G6PD 活性は正常值の約 10〜20\% だが，ファビズム は認められず，ファビズム症状を示すコーカシアン男性 では正常値の $0 \sim 6 \%$ であり，また，溶血後黒人では若 い赤血球数が急増するのに比ベコーカシアンでは増加し ない。一般に酸化還元反応を受けやすい物質の存在下で hemoglobinより生ずる過酸化水素は還元型 glutathione, glutathione peroxidase,により処理され, 生 じた酸化型 glutathione は NADPH と glutathione reductase により還元型 glutathione に再生され，消費 
<smiles>CC(O)(COc1c(O)nnc(N)c1O)C(C)(O)C(N)=O</smiles>

Vicine (15)<smiles>Nc1nc(O)nc(O)c1OOC(=O)O</smiles>

Convicine (16)
図 5 ソラマメ種子中のファビズム原因物質の構 造式

された NADPH は glucose-6-phosphate と NADP+ から G6PD により補給される．この G6PD を欠く赤 血球では還元型 glutathione が非可逆的に酸化され， 処理されない過酸化水素が赤血球膜を損傷し，溶血を引 き起こすことになる. 赤血球の構造維持に還元型 glutathione が不可欠であるということは, glutathione synthetase, glutathione peroxidase, glutathione reductase 等を欠くヒトが溶血しやすい，ということか らも支持される．ソラマメ種子中のファビズム原因物質 は vicine(15), convicine(16) のアグリコンである divicine と isouramil とされており，ピリミジン塩基で あるこれらアグリコンはきわめて容易に酸化される，過 酸化水素による溶血に対する selenium の保護効果は, glutathione peroxidase の 4 個のサブニニットがそれ ぞれ 1 個の selenocysteine を含むためと考えられる (図 5).

\section{2) Selenium 含有化合物}

土壤中の selenium 含量は $0.2 \sim 0.3 \mathrm{ppm}$ 程度であ るが，この土堙中の selenium 含量をはるかに越えて， 多い場合には $15,000 \mathrm{ppm}$ もの selenium を蓄積する 植物がある．代表的なものはマメ科のレンゲソウで，主 要成分は非タンパクアミノ酸の S が Se で置き代わっ た selenomethylselenocysteine (17), selenocystathionine(18) である. selenium 蓄積植物によると卜 の中毒症状は, 激しい下㢉, 嘔吐, それに続く脱毛で, 家畜の中毒も報告されているが，ヒトにとって危険なの は，むしろ高 selenium 含量土壤に生育した通常の植物 による慢性中毒であり, selenium 蓄積 型ではない通常 の植物では, selenium はタンパクアミノ酸の $\mathrm{S}$ が $\mathrm{Se}$ で置き代わった selenomethionine, selenocystine と<smiles>C[Se]C(N)C(=O)O</smiles>

Selenomethylselenocysteine (17)

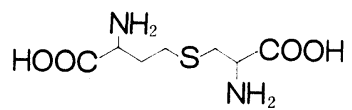

Selenocystathionine (18)
図 6 Selenium 含有化合物の構造式
して含まれている. selenium の最低必要量は $22 \mu \mathrm{g} /$ 日, 安全攝取範囲は 50 400 $\mu \mathrm{g} /$ 日, とされているが, 中国 等の selenium 中毒発生地域の selenium 平均捸取量 は, $1338 \mu \mathrm{g} /$ 日となっている(図 6).

\section{栽培地域が比較的限定されている食飼料植物に 存在する有害物質}

1) ラチロゲン (Lathyrogens, ラチリズム原因物質) マメ科 Lathyrus 属の種子，特に L. sativus による 中毒が，それがかんばつなど条件の悪いところでも良く 成育することから，主にインドで問題になっている. L. sativus のタンパク質は tryptophan, methionine 以外の必須アミノ酸含量が高く, 特に lysine が豊富に 含まれているが，同時に含まれる $\beta$ - $N$-oxalyl- $\alpha, \beta$-diaminopropionic acid (ODAP) (19) がヒトに対して 神経の損傷，下肢の麻瘏等の症状を発現させる.これを 神経性ラチリズムといい, ODAP によりシナプス周辺 に glutamic acid が蓄積してしまうためとされている. その他ヒトに対しての関与は不明だが，実験動物に神経 性ラチリズムを引き起こす物質として他の Lathyrus 属の植物から $\alpha, \gamma$-diaminobutyric acid, Vicia 属の カラスノエンドウから $\beta$-cyanoalanine が報告されて いるが，前者は ornithine transcarbamylase 阻害， 後者は cystathionine $\gamma$-lyase 阻害が関与していると 考えられている. 一方, Lathyrus 属のスイートピーか ら単離された $\gamma$-glutamyl- $\beta$-aminopropionitrile (20) は，実験動物に骨性ラチリズムと称する骨格異常を引き 起こす．L. sativus にはこの物質は含まれず，骨性ラチ リズムはヒトでは問題になっていない. $\beta$-aminopropionitrile は結合組織タンパク質の collagen, elastine 等の架橋構造形成を阻害するため結合タンパク質が正常 な網状構造を取れなくなり，結合組織の弱化，軟骨や骨 形成の異常が引き起こされる，網状構造形成の第一段階 はペプチド鎖中の lysyl 残基の酸化による allysine 残 基の生成であり， $\beta$-aminopropionitrile はこの反応を 触媒する lysyloxidase を阻害する．このような異常が 血管に現れた場合を特に血管性ラチリズムといい，血管 壁の弾力性が失われ動脈瘤を形成するようになる(図 7).<smiles>N#CCCNC(=O)CCC(N)C(=O)O</smiles>

$\beta-N$-oxalyl- $\alpha, \beta$-diaminopropionic acid (ODAP) (19)

$\gamma$-Glutamyl- $\beta$-aminopropionitrile (20)

図 7 ラチリズム原因物質の構造式 


\section{2) Mimosine}

樹木性マメ科植物のギンネムは乾燥，やせた土地にも 強く, チッ素固定能を持ち, 生産性, 食味, 共によく食 糧源として期待されているものであるが，問題となるの が，葉，種子に含まれる非タンパクアミノ酸の mimosine(21) である. 反忽動物では mimosine から生ずる 3,4-dihydroxypyridine のケト型の甲状腺肥大作用に より成育が悪化するが，単胃動物ではそのような影響は なく，特徵的な症状は脱毛で，これは mimosine の強 い cystathionine synthase 阻害作用による cysteine 合成阻害のためと考えられる。その他，mimosine は protocollagen の proline 残基の水酸化を阻害し, hydroxyproline 含量の少ない，したがって collagenase による分解を受けやすい collagen を生ずる。また， mimosine は pyridoxal phosphate と反応して $\mathrm{B}_{6}$ 酵素 を阻害し，さらに tyrosine との構造類似から tyrosins decarboxylase, tyrosinase を阻害する(図 8).

\section{3) Hypoglycin}

ムクロジ科植物のアキー果肉による中毒は，地域的に はジャマイカ等に限られているが，原因物質，作用機 構，等が明らかになっているので紹介する.最も特徽的 な症状はジャマイカ嘔吐症といわれる激しい嘔吐, 急激 な血糖值低下で，正常值（血液 $100 \mathrm{ml}$ 中 glucose 約 $100 \mathrm{mg}$ ) の数\%にまで低下し，この際脂肪肝が認めら れる．血糖值低下の原因物質は hypoglycin (22) で, 体 内で $\alpha$-methylene cyclopropylacetic acid に代謝さ れ，これが脂肪酸の $\beta$-酸化を阻害するためエネルギー 要求を満たすために貯蔵 glucose が消費され，さら に糖新生反応のための ATP, NADH 等が不足するこ とから糖新生反応も阻害され急激な低血糖を引き起こす ことになる．脂肪酸の $\beta$-酸化阻害は，脂肪酸が acylcarnithine となってミトコンドリア内に移行する過程

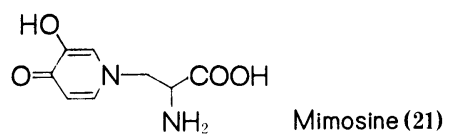

図 8 Mimosine の構造式
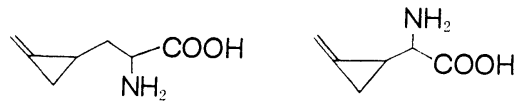

Hypoglycin (22)

$$
\begin{aligned}
& \alpha \text {-Methylene- } \\
& \text { cyclopropylglycine (23) }
\end{aligned}
$$

図 9 血糖值低下の原因物質の構造式
の阻害, 次にミトコンドリア内での acylCoA dehydrogenase の阻害，により生ずる，さらに同酵素阻害によ り蓄積した acylCoA エステルにより糖新生反応の第一 段階の酵素である pyruvate carboxylase が阻害され るため，ここでも糖新生が抑えられる。一方，激し い嘔吐は isovalerylCoA dehydrogenase 阻害による leucine 代謝阻害により isovaleric acid が蓄積するた めとされている．同じムクロジ科のレィシには hypoglycin の低級同族体である cyclopropylglycine(23) が存在し，実験動物で低血糖を引き起こすことが認めら れているが，ヒトでの中毒は知られていない(図 9)。

\section{特殊な条件下でのみ謇作用を引き起こす物贸}

\section{1) Coprine}

ヒトヨタケは多量に摂取しても何の問題もないが，ア ルコールと一緒に摂取すると血中 acetaldehyde レベ ルが上昇し，心悸六進，嘔吐等の症状を呈する．原因物 質は coprine(24) で，その加水分解で生ずる不安定な aminocyclopropanol とさらに分解した cyclopropanone hydrate が共に acetaldehyde dehydrogenase を阻害するため acetaldehyde が蓄積することになる (図 10).

\section{抗ビタミン物留，発癌物㬏}

以上に記した反栄養素のほか，食飼料素材にはビタミ ン構造を修飾，あるいは破壊したり，ビタミンと類似構 造を持つことで競合することによりビタミンの作用を失 わせる抗ビタミン物質, 捸取された後求電的アルキル化 剂の生成等により遺伝子やタンパク質と反応し損傷を与 える発癌物質が存在する場合がある。

抗ビタミン物質としてはいくつかの酵素が知られてお り，表 1 の脚注にも記した thiaminase, lipoxygenase はそれぞれ抗ビタミン $\mathrm{B}_{1}$ および A であるが，その他， インゲンマメ, ダイズ, アルファルファには tocopherol oxidase が含をれ抗ビタ ミン E 作用を示す. 多くの野 菜, 果実に含まれる ascorbinase は ascorbic acid をビ タミンC効力が半分のデヒドロ体に酸化する．低分子の 抗ビタミン物質としては亜麻種子の linatine $(25)$ による 抗 pyridoxine 作用がよく知られており，加水分解によ

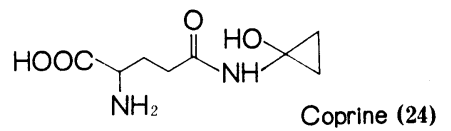

図 10 Coprine の構造式 
<smiles>NC(CCC(=O)NN1CCCC1C(=O)O)C(=O)O</smiles><smiles>C=Cc1ccc2c(c1)OCO2</smiles>

Safrole (28)<smiles>CC=NN(C)C=O</smiles>

Gyromitrin (29)<smiles>CN(O)NCOCCO</smiles>

Cycasin (26)

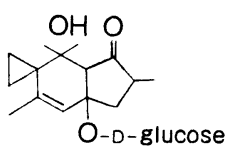

Ptaquiloside (27)

図 11 抗ビタミン物質および発癌物質の構造式

り生ずる 1-aminoproline が活性本体である. Mimosine の抗 pyridoxine 作用についてはすでに記したが, その他ギンナンによる痙卛等の神経症状の原因の一つは 抗 pyridoxine である 4-methoxypyridoxine である とされている.

発癌物質としてはソテッ科植物に含まれる cycasin (26) が良く知られているが，その他，ワラビの ptaquiloside(27), キク科キオンの pyrrolizidine アルカロイ ド，モクレン科，クスノキ科の精油成分の safrole (28), マッシュルーム中の gyromitrin (29), agaritine (30), さらに分布の広い quercetin, kaempherol 等のフラボ ノールに発癌性, あるいは変異原性が 報告されている (図 11).

\section{おわりに}

以上，主に植物性の食飼料素材中の代表的な有害物質 を簡単に紹介したが，通常の食飼料摂取状況下ではこれ ら有害物質により症状が発現することはほとんどないと 考えてよい，危険なのは，食飼料不足，あるいは極端な 健康法, ダイエット等により特定の食飼料のみを摄取す る場合であり，少量多種，という食事が栄養素のバラン スをとるという上でも，さらにとれぞれの食品に含まれ る可能性のある有害物質の影響を防ぐ上でも重要であ る.

多くの例で反応性の高い物質は安定な配糖体として蓄 えられており,また, 配糖体より例は少ないが $\gamma$-glutamyl 結合により安定化しているものも数例挙げた. 反 栄養素ではないが，ネギ属，マッシュルーム等の特徽的 なフレーバーの多くの前駆体は $\gamma$-glutamyl 誘導体で ある。

食品素材成分による症状発現に個人差のあるものの例 としてはファビズムのみを挙げたが，フェニルケトン尿 症等遗云的なアミノ酸代謝酵素欠損による疾患, 多くの 食品タンパク質に対して認められるアレルギー症状, な
ど通常は栄養上重要な食品成分により重い症状が発現さ れる例もある。

食品学, 食品加工学等の目的の一つ之して食品素材か らの上記のような有害物質の除去があり, 食品素材には できるだけ手を加えず自然のますに近い状態で攝取する ことが望ましい，というよく聞かれる考光方の危険さを 指摘しておきたい，同様な考光方に属するものであろう が，食品あるいは食品素材中の酵素活性が保存条件によ って低下することから，そのような条件およびその条件 で保存した食品あるいは食品素材を否定するような説が あるが，ある生体成分がその生体においてもっている意 義とそれを食べる側がその物質に求める意義を混同して はならないだろう。䣼素の場合, その酵素作用はそれを 含む生体が統制のとれた生体反応を行なっていく上で必 須であるが，それを食べる側にとってはアミノ酸の供給 源であるタンパク質として必要なのであり，一般に䤃素 作用のような強い生理作用をもたないただのアミノ酸結 合体として供給されるほうが望ましいと考えられる。そ の関連で，立米が食品としていかに白米より優れたもの であるかを示すためにある食品製造関係者が挙げていた 例 (ラジオ放送) は興味深い. 氏によれば，「立米と白米 をシャーレに入れて水をはり，1 週間ほど置くと白米は 腐ってしまうが，玄米は腐るどころか芽が出てくる．白 米と違って立米は生きており, 立米がいかに食品として 優れているかがわかる．白米という字を並べて書くと粕 という字になる」ということであったが，粕という字の こと，および肧芽を除去した白米からは芽が出るはずが ないこと，は別にして，白米が腐ったということは微生 物が繁殖したということであり，氏の挙げた例は，白米 のほうが他の生物に利用されやすいということを示すも のであろう，玄米が生きている，ということはあくまで もコメという生物として生きているということであり, 氏の説では, 食う側にとって利用しやすい栄養素の集ま りの状態より他者による捕食に抵抗している状態のほう 
が食品として望ましい，ということになる.

食品素材保存においても，素材自体に内在する醉素の 作用による変質を防ぐことは微生物の繁殖による腐敗を 防ぐことに次いで重要であり，ほとんどの場合内在酵素 は失活していることがむしろ望ましい。

最後にポストハーベストについて触れておきたい，多 数の著者の共著による食品加工学の教科書に,「収穫後 の農作物の商品価值を高める目的で，これを化学薬品で 処理するという言語道断な“ポストハーベスト処理”が 取り沙汰されている。このような悪質きわまりない行為 は繁しく取り締まらねばならない」，という教科書とは 思えない激しい調子の記載がある．生物が生きている間 は，中枢の指令系に末端で受け取る刺激がたえずフィー ドバックされ，そのつど適応した指令を発することによ り, 膨大な数の化学反応が統制のとれた順序, 速度で整 然と進行し，生体の恒常性が維持されているが，生物が 死んでしまいこの中枢の指令系が働かなくなると，膨大 な数の化学反応のそれぞれを触媒していた醅素群のうち のあるものは失活し，活性の残っているものは勝手に働 きだし，その結果として変質，分解が進行していくこと になる．これが，ほとんどの場合食品素材の酵素は失活 しているほうが望ましい，と上述した理由の一つなのだ が，さらに種々の防御反応も失われることから，微生物 による腐敗も受けやすくなる。ポストハーベスト処理が 食品素材の微生物による腐敗を防ぎ，同時に内在醭素に よる変質を抑えることを目的とするならば，この技術は “言語道断”ではなく，食資源確保のための有効な手段 であるということにならう. 収檴した食品素材の保存 性, 利用性が向上するようなより良い処理方法を求めて いくことは食品加工学の大きな目的の一つのはずであ る.ポストハーベスト処理という食資源確保のために役 立ちうる技術を, 食品加工学の教科書でトータルに否定 してしまう姿勢には強い疑問を覚える．改めていうのも 䎵ずかしいほど当たり前のことだが，ポストハーベスト 処理に限らずどんな技術も利用方法が問題なのであり， 有望な可能性をもつ技術をトータルに切り捨てる，とい
う方向は危険であうう。たとえば，今後非常に重要な夕 ンパク質資源になると思われる単細胞タンパク質 (石油 タンパクと呼ばれた), 食品の保存に種々の利点を有す る放射線処理，等の実用化はもとより基礎研究さえも日 本で遅れてしまった大きな理由として, 主に名前が与え るマイナスイメージによりそれらが世論でトータルに否 定されてしまった，ということが挙げられるからであ る.

\section{参 考 文 献}

本小論の珄格上，成書，総説の久をあげる，なお，本 文中で否定的に引用した著書は記していない。

1) “Toxicants Occurring Naturally in Foods," Committee on Food Protection, Food and Nutrition Board, National Research Council, Washington DC, 1973

2) “Chemical Toxicology of Food," ed. by C.L. Galli, R. Paoletti \& G. Vettrazzi, Elsevier/North-Holland Biomedical Press, New York, 1978

3) E. C. Miller \& J. A. Miller: Biochem. Nutr. IA, 27, 123 (1979)

4) "Toxic Constituents of Plant Foodstuffs," ed. by I.E. Liener, Academic Press, New York, 1980

5) T. Kasai \& P. O. Larsen: Fortschr. Chem. Organ. Naturst. 39, 173 (1980)

6) "Natural Toxicants in Food," ed. by D. H. Watson, Ellis Horwood Ltd., Chichester, 1987

7) A. Albert: "Xenobiosis," Chapman and Hall, London, 1987

8) W. Majak: J. Toxicol. Toxin Rev. 11, 1 (1992)

9) S. Hatanaka: Fortschr. Chem. Organ. Naturst. 59, 1 (1992)

10）フォンE.リンドナー（芳賀, 赤木訳)：食品の毒 性学, 講談社, 1978

11) 山崎幹夫, 中嶋軲躬, 伏谷伸宏: 天然の毒, 講談 社, 1985

12）石黒俊治：食品之安全性，南山堂，1989

13）深海 浩：生物たちの不思議な世界, 化学同人, 1992

14）生物毒の世界，日本化学会編，大日本図書，1992

15) 食品科学 (第 2 版), 安井 勉, 桐山修八編, 三共 出版, p. 200, 1992 